\title{
Structure and Challenges of Nigeria's Overseas Diplomatic Missions
}

\author{
Johnson Olaosebikan Aremu, PhD \\ Department of History and International Studies, \\ Ekiti State University, Ado- Ekiti, Nigeria
}

doi: 10.19044/esj.2016.v12n11p525 URL:http://dx.doi.org/10.19044/esj.2016.v12n11p525

\begin{abstract}
This paper is committed to an historical exploration of the structure, functions and challenges of Nigeria's overseas missions since inception till 1999. To this end, it employed the eclectic method of enquiry, adopting a combination of historical and descriptive methods of data collection. The study relies heavily on secondary data sourced from journal articles, textbooks, newspapers and magazines and other relevant materials including government gazettes. It also benefitted significantly from primary sources of information. Facts and information obtained were subjected to corroboration and critical analysis using qualitative method. This was done in order to enhance objectivity. The paper observes that Nigeria's overseas missions fall into two broad categories, namely, the diplomatic and consular missions and are of varying sizes. These missions have vigorously pursued the country's national interest over the years with mixed results of success and failures, amidst daunting challenges.
\end{abstract}

Keywords: Nigeria, Foreign Policy, Diplomatic Service, Ambassador, National Interest

\section{Introduction}

The Nigerian diplomatic service was established by the Tafawa Balewa-led federal government in 1957, three years before Nigeria's independence, to prepare the nation for its foreign representation after independence. ( Orjiako, 2010:96) It started as the External Affairs division of the Prime Minister's office, under the supervision of a British colonial official, Mr. E. K. Williams. (Fafowora, 2008). As Brownlie (1980:348) has rightly observed, all independent states have the legal capacity to establish diplomatic relations. This probably explains the fact that one of the first sovereign acts of most states that gained independence after the Second World War, including Nigeria, was membership of the United Nations and 
the establishment of diplomatic relations with other states. Consequently, it is no surprise that barely a week of her independence; Nigeria became the $99^{\text {th }}$ member of the United Nations on 7 October, 1960. She quickly established a Permanent Mission to the UN in New York; raised the status of the Commissioner's office in London to that of a High Commission, just as the Nigerian Liaison office in Washington DC was elevated to the status of an Embassy. Opening of other Embassies and High Commissions soon followed suit to the extent that by March 1961, Nigeria had established eleven diplomatic missions’ abroad (Adeniji, 1990:164). The number rose to thirty-three in 1963; forty-six in 1970; ninety in 1982, ninety-seven in 1999 and two hundred and ninety in 2015. Recently, however, it was reduced to two hundred and nineteen by President Buhari in 2016 (Goldstar, 2003:243253; Opara,2016).

Meanwhile, recruitment of the pioneer staff members of what later came to be known as Nigeria's Federal Ministry of Foreign Affairs started between 1957 and 1958. The officers were recruited by the Federal Public Service Commission through the Federal, Eastern, Northern and Western Regional Public Services. According to Nwosu (1991:154), five of these officers came for the public service of the federation, two each came from the public service of the three Regions and one was a fresh graduate from the Oxford University. Regional Governments were also invited by the Federal Government to recommend officers from their various public services that might be willing to accept secondment into the Foreign Service and later transfer their services to the Federal Public Service (House of Representatives Sessional Paper No. 11 of 1956). According to Jolaoso (1991:11-13), the pioneer foreign service staff were: Omotayo Ogunsulire, Dickson Igwe, Philip Asiodu, Leslie Harriman, Adedokun Haastrup, Aminu Sanusi, Soji Williams, John Mamman Garba, Chike Chukwurah, Chukwuemeka Ifeagwu, Olumide Omololu, John Ukegbu, Olujimi Jolaoso, Olusola Sanu, Victor Adegoroye, Edward Enahoro, Sule Kolo, Ignatius Olisemeka and George Dove-Edwin (Azuh,2011; Jolaoso,1991:11-13; Fafowora,2008).

It is essential to note that the Prime Minister, Sir Abubakar Tafawa Balewa, articulated the basis for the recruitment of these pioneer officers during a Foreign Policy debate in the House of Representatives in Lagos on 27 February, 1958, when he declared that:

After independence, Nigeria will largely be judged by the quality of the representation overseas, its diplomatic service. It is very easy to say that Nigeria should only be represented by the best; it is rather more difficult to define what the best is. In 
determining the qualifications for the new service, government has these considerations in mind: first, the candidate should be well educated; second, he must be or should be trained to be a civil servant divorced from politics, and third, he must acquire proficiency in languages. Our training policy was based on these principles (Jolaoso, 1991:13).

Without mincing words, the foregoing submission of Balewa shows that the government placed a great premium on staff training and development to maintain a high calibre staff profile in the Ministry of Foreign Affairs. This no doubt was to enhance efficiency and effectiveness in the operations of the Ministry, then and in the nearest future. It was in the realization of this principle of adequate training for staff of the ministry that the first batch of officers of the Ministry was sent to the Nigerian offices in London, Khartoum, Jedda, Washington, Santa Isabel, and Libreville for training; the emphasis then being the acquisition of overseas experience. During this same period, on- the- job training was also offered to a few Nigerians in British missions in Rio de Janeiro, Bonn, The Hague and Ottawa. Some of these trainees were encouraged to acquire proficiency in the use of French or German languages (Aluko, 1970:35; Federal Republic of Nigeria, 1964:21-22). These officers constituted the nucleus of the staff of the External Affairs Division in the Prime Minister's office, which metamorphosed into a full-fledged Ministry of Foreign Affairs and Commonwealth Relations at independence in 1960.

\section{Rationale for the Establishment of Diplomatic Relations}

One major rationale for Nigeria's establishment of diplomatic relations with other countries of the world was, and still is, the great importance the government attaches to maintaining friendly relations with other independent countries of the world. This is hinged on the belief that diplomacy facilitates communication and regular interaction between the leaders of states and other entities in world politics. As such, establishing diplomatic relations with other countries was seen as an important tool for minimizing friction in interstate relations; promoting the security of states; and establishing some form of international order (Kawonishe, 2003:1).

Another major reason that probably accounts for Nigeria's establishment of diplomatic missions, even right from independence, is the perceived need to use diplomatic exchanges as instruments of administrative and economic cooperation with other states. This probably explains why attention was given to establishing missions in contiguous states and in states 
within the African and West African sub-region in order to support positive and cooperative efforts for development.

Furthermore, the rapid expansion of Nigeria's overseas representation may also be regarded as a reflection of Nigeria's global, political and economic interests as defined by Alhaji Sir Abubakar Tafawa Balewa, Nigeria’s first Prime Minister (Idang, 1973:112). In fact, as Johns (1979:270) has rightly observed, the establishment of diplomatic missions in other countries by states across the globe is an indication of the foreign policy orientation of a given state. It is indeed a reflection of the deliberate action or reaction of states and is a tangible measure of foreign policy behaviour of independent states.

\section{Administrative Structure of Nigeria's Overseas Missions}

Nigeria's overseas missions fall into two broad categories, namely, the diplomatic and consular missions. While the Embassies, High Commissions, Permanent Delegations/Missions and charges d' Affairs are called diplomatic missions and are located, as a rule, in the capital cities of the host states for the purpose of ensuring proximity to the Heads of State and Foreign Ministers of the Host States; Nigerian Consulates and Area Offices across the globe are grouped together as Consular Missions. They may be set up in some important industrial or commercial centres on the authorization of the host government and not necessarily in the capital cities.

It is essential to note that an Embassy is the highest rank of diplomatic establishment recognized in international law, and its status is usually equated with that of the Permanent Delegation to the United Nations (Padelford and Lincoln, 1967: 314). However, in keeping with Commonwealth practice, Commonwealth Governments are represented in the capitals of other Commonwealth countries by High Commissioners who are equal in status with Ambassadors.

Equally important to note is that the structure of Nigeria's overseas missions varies according to the size, importance and the nature of Nigeria's needs in the various countries. Some missions are very large and undertake numerous and complex activities, while some are very small and attend to minimal activities. Here, the case of the Nigerian High Commission in London with total staff strength of one hundred and ten officers spread across eleven sections, and Nigerian High Commission in The Gambia, staffed by only one First Secretary who performs multiple functions simultaneously as at 1980, is a good example (Diplomatic List, Foreign and Commonwealth Office, 1980:54-56). The difference in size notwithstanding, it is important to note that a typical Nigerian Overseas Mission is organized in a hierarchical structure and divided into several sections or units in charge 
of specified duties for the purpose of enhancing effective and efficient performance of the duties of the mission.

The general format in most of the Nigerian missions abroad is that the Head of Mission, who may be designated as an Ambassador or High Commissioner is at the apex of the hierarchy. As the chief representative of the Government and people of Nigeria in their respective countries of accreditation, they are responsible for the co-ordination of affairs of the Mission. Article 148 of the Republican Constitution of 1963 empowers the President, acting on the advice of the Prime Minister, to appoint Heads of Nigeria's diplomatic missions. The 1979 and 1999 Constitutions of the Federal Republic of Nigeria however empower the Executive President to appoint Heads of Mission upon ratification by the National Assembly. A further guide on the appointment of Heads of Mission is also contained in Article 8(1) of the Vienna Convention on Diplomatic Relations (VCDR) of 1961 which stipulates that such Heads of Missions and other diplomatic staff of the mission should, in principle, bear the nationality of the sending state.

Upon his appointment, His Excellency, the Nigerian Ambassador/High Commissioner performs important functions contrary to the erroneous view of many people who see him as no more than a "social parasite”, or a public relations man sent abroad to lie for his country, to make friends and contacts for himself and Nigeria and enjoy himself (Ogunbambi, 1986:162). Such views obscure the actual tasks and important functions performed by the Head of Mission in the world of complex bilateral and multilateral diplomacy. Some of these functions are highlighted below.

The primary duty of all Nigeria's head of diplomatic missions abroad is to represent the government of the country in the receiving state. The missions present the policies of the Nigerian government to the host states. As such, they are expected to carry out faithfully the instructions given by the home governments. Diplomatic Missions also serve as the agent of communication between the government of Nigeria and the governments of their receiving states. Missions are therefore expected to do such things as attending the celebration of the other state's national day, holidays or expressing condolences upon the death of other state's officials. He is also charged with the responsibility of delivering goodwill messages of Nigerian governments to the leadership of the host state. As the symbols and spokesmen of the country in foreign lands, their ability to communicate effectively; their demonstrated knowledge of Nigeria, as well as their sensitivity and intelligence project a credible interest in their countries of domicile. This is very helpful to the successful projection of the image of the country to the outside world.

The Head of Mission must promote the national interests of Nigeria. Such interests which he is expected to promote include political stability, 
security, export promotion, foreign aid, the protection of citizens abroad, and an effective and rigorous presentation of Nigeria's points of view on regional and global issues. In other words, the duty of the Nigerian Head of Mission is to preserve and advance Nigeria's national interests. In doing this, he observes events abroad, monitors development in the host state; defends the interests of Nigeria; reports back to his home government and presides over the implementation of the country's policies abroad.

Another major duty of the Head of Mission is managerial in nature. In very large posts, the Ambassador must take a personal interest in the efficiency and welfare of the men and women who serve under him. Similarly, Nigerian nationals resident in his state of domicile sees him as a counselor and leader. Hence, the Head of Mission has the responsibility for enhancing and promoting the security of such Nigerians and must protect their interest from time to time as far as the law permits. This he does by helping them seek redress where their rights are being infringed upon. Even in times of hostilities, such as civil or international conflicts, he has the responsibility to evacuate Nigerian nationals from the trouble-spot areas to a safe haven or take them back to their home country. In other words, the Head of Mission is expected to be sensitive to the needs of Nigerians who may be resident in their country of accreditation or even visiting. Prominent in this category are government delegations, media representatives, students, academics, and businessmen.

The Head of Mission is also a public relations officer of his country as he attempts to promote friendly relations between the sending state and the receiving state. First of all in this direction, he tries to understand the country which he serves, its conditions, its mentality, its actions, and its underlying motives. He must be able to explain these things clearly to his own government. The Ambassador must also seek means of making known to the government and people of his host state the purpose, hopes and desires of his country. Since diplomatic relations are established between independent countries by mutual consent; diplomatic missions are expected to help cement and promote the existing friendly relations between their countries of origin and the countries to which they have been accredited. Diplomats, however, do not just make efforts to promote friendly relations with members of the government elite alone, but also with various interest groups and professionals within their states of domicile; as well as members of the diplomatic corps at large. Apart from this, diplomats also try to create goodwill for their countries and its policies by delivering lectures and other speeches, attending dinners and parties as well as initiating foreign assistance projects.

In a related development, the Head of Mission is expected to perform the function of information gathering and reporting. Hence, as the chief 
diplomat of his country in a given country, he has the duty of ascertaining, by all lawful means, conditions and developments in the receiving state, and report, thereon to the government of the sending state. These reports cover nearly every conceivable subject from technical studies to appraisals of the psychology of other nations. The Head of Mission, relying on the services of other diplomatic agents, is expected to observe, analyze and report on political, social and economic conditions and trends of significance in the country to which he was accredited. Such reports are expected to be accurate reflection of the local political, economic, social, educational, and technological situations and strategies of the host state. This is why, the periodic reports, known as diplomatic cables, sent back home from embassies and legations cover different aspects of relations with other countries. The importance of such diplomatic reports cannot be overemphasized as they serve as the raw materials of foreign policy since foreign policy cannot be formulated in a vacuum without adequate knowledge of other countries (Palmer and Perkins, 2001: 86).

Again, a major traditional duty of diplomatic missions is negotiation. This may be referred to as the pursuit of agreement by compromise and direct personal contact. Here, diplomats stand out as instruments of bargaining for their country. The subject of negotiation ranges from the drafting of a wide variety of bilateral and multilateral agreements, embodied in treaties, protocols, conventions and other documents of political, economic, technical and social nature ((Palmer and Perkins, 2001:85). As it is with most other missions of the world, Nigerian diplomats handle more formal aspects of negotiation while the technical aspects are left to specialists. Increasingly, however, the resident Ambassador or High Commissioner has been by-passed in major negotiations in contemporary diplomatic practices. This however does not in any way suggest the downgrading of diplomacy in resolving interstate disputes.

However, it should be noted that the above-mentioned duties of a Nigerian Head of Mission are not exhaustive. As a matter of fact, the Federal Government of Nigeria can really neither fully define for the ambassador the totality of his particular mission nor prepare him for every unexpected contingency. It is therefore required of an Ambassador to have a proper understanding of the foreign policy focus of the country and see how such policies apply to the country where he is stationed. It is thus a matter of expediency that Nigerian Ambassadors are men of integrity and great intelligence to be able to cope with the extremely varied and complex tasks of their missions. There is also the need for them to keep abreast of recent developments in modern diplomacy in the global arena as well as applying it to promoting the country's interests in their states of domicile. Furthermore, as the arrowheads of a vibrant foreign policy driven by Nigeria's national 
interest, it is important that these diplomats project the aspirations, priorities and paramount interests of the country in their explanations of critical issue involved in Nigeria's socioeconomic, cultural and political circumstances (Nigerian Compass, 26 June, 2012).

Meanwhile, in the running of the affairs of Nigeria's Foreign Missions, Heads of Missions largely employed an open administration system involving consultation before final decisions and recommendations are made on vital issues. This involves regular meetings and consultation between the Head of Mission and very senior officers for cross-fertilization of ideas on issues of concern to the mission, as well as the preparation of memoranda on important issues and problems for closer scrutiny and examination. This inbuilt open system policy allows for wide consultation and constructive criticisms thereby benefiting from reliable information that has helped in improving the quality of policy advice, policy recommendations and policy decisions.

Next in rank to the Head of Mission is the Minister-Counselor. He is a career diplomat, an External Affairs Officer, who represents the Permanent Secretary of the Ministry of Foreign Affairs. He is the Head of the Chancery, the Mission's secretariat. The Chancery may be regarded as the heart of the mission and the hub from which instructions within the mission radiate and advice from Home Headquarters converge. The Minister-Counselor may be referred to as the Principal Adviser to the Head of Mission because he advises the Head of Mission on political matters and briefs him on all other matters of importance. He is responsible for carrying out the day-to-day administration of the Mission. His numerous duties in this direction include:

i. co-ordination and supervision of chancery reports;

ii. preparation of annual confidential reports for the countersignature of the Ambassador;

iii. controlling the vote of the mission and by so doing presiding over the Departmental Tenders’ Board of the Mission;

iv. coordination of the activities of the various sections of the mission; and

v. acting as charge d'Affaires of the mission in the absence of or the incapacitation of the Head of Mission.

Directly under the Head of Chancery is an Administrative section with a couple of sub-sections each headed by a Counselor or First Secretary. The Counselor or First Secretary sees to the day-to-day running of the sections over which they preside. Such sections may include; property, political matters, personnel and general administration. In large missions, there may be Second and Third Secretaries. These three Administrative Attaches share among themselves administrative duties such as custody of classified documents, control, maintenance and disposition of official 
vehicles and drivers, discipline of local staff; maintenance, repair and security of government property; typing of reports from all political officers and protocol duties. Apart from the Administrative Attaches, there is also an Accounting officer who is called the Financial Attaché. This position is occupied by a professional accountant who handles general accounting matters such as preparation of salaries, wages and allowances, banking and treasury transactions as well as other accounting related matters.

The above-mentioned duties have occupied the attention of Nigeria's overseas missions over the years with varying degrees of success in their accomplishments. Meanwhile, most Nigerian missions are faced with a number of challenges and difficulties that have hampered their efficiency and effectiveness in the performance of their statutory functions and duties. It is therefore considered necessary to examine such challenges facing Nigerian diplomatic missions at large.

\section{Challenges Facing Nigeria's Overseas Diplomatic Missions}

A myriad of challenges confront Nigerian diplomatic missions spread across the globe. Though it may not be possible to discuss peculiar problems of each mission in this paper, an attempt is made in subsequent paragraphs to identify the general problems facing all the missions as observed by the staff of the Ministry of Foreign Affairs, professionals in the field of international relations as well as former and serving diplomats.

Top of the list of these numerous challenges is the inadequacy of qualified personnel to staff the missions. It is observed that the numbers of staff posted to Nigeria's foreign missions are not only inadequate in number, but are equally most ill-equipped for the tasks of the missions ((Idang, 1973:112; Olusanya, 1990: 526). According to some members of the Ministry of Foreign Affairs, Abuja and some embassy staff in Cotonou, Benin Republic and Accra, Ghana, who pleaded for anonymity, three main reasons may be advanced for this ugly development. In the first instance, it was noted that at the outset of the Ministry of Foreign Affairs as a whole and the Nigerian foreign missions in particular in the early days of independence; efforts were made by government to ensure that the highest calibre of men was recruited into the service while great emphasis was placed on training in order to enhance good performance. It is, however disheartening to note that the quality control which was an essential feature of the Foreign Service in those early years has been largely eroded. Secondly, like other institutions in the country, the Foreign Service has become highly politicized to the detriment of the maintenance of standards. This has been saying a lot on the level of competence, effectiveness and efficiency of diplomatic staff posted abroad. Thirdly, for reasons of lack of fund, there has been a kind of presidential ceiling (Madueke, 2009) on the number of officers posted to 
Nigeria's foreign missions. This has been affecting the activities of the missions as members are not always competent in handling technical matters for which they were not trained.

Equally daunting a challenge to Nigeria's foreign missions has been the inadequacy of fund. According to Fafowora (2001), "the Foreign Service has been generally underfunded in recent times and has suffered a lot of undeserved neglect to the extent that many of the Embassies owe on their rent, and the allowances of their officials were often in arrears”. Hence, one major complaint often heard from many diplomatic missions is that their task of implementing and servicing Nigeria's foreign policy abroad has always been inadequately funded by government. This ugly development, according to Gbenga Ashiru, Minister of Foreign Affairs, has been occasioned by the cut in the Ministry of Foreign Affairs' budget over the years as a result of the global economic meltdown (Financial Nigeria, 2012). This problem of inadequate funding of foreign missions has been affecting the smooth running and effective performance of these missions abroad. Most of the missions have at different times faced a lot of embarrassment for their inability to settle ordinary electricity and telephone bills. The situation was so bad that Madueke (2009) had to lament in his speech before the House of Representatives Committee on Foreign Policy in 2008 that: "we have a mission where the Ambassador's car would have to be pushed on the road in an important capital in the world (referring to New York). It does great damage to our image."

This observation was also affirmed in the submission of Bola A. Akinterinwa, cited in Akinyemi (1986) that :

generally... budgetary allocation to foreign affairs has always been poor. Our embassies are often underfunded. In fact, it is on record that information officers posted to strategic diplomatic missions have been summoned to the courts in their receiving states for nonpayment of house rents. This situation arises because the government and relevant ministries do not often make available to their staff the necessary funds. As a result, such officers are embarrassed even if they claim immunity from court prosecution.

It is obvious that when diplomatic missions constantly face financial embarrassment abroad, they will not be able to pursue their tasks and functions with the much needed vigour and confidence. This therefore informs the need to improve and strengthen the financial resources available to Nigeria's foreign missions. Over the years, Nigeria's Foreign Affairs 
Ministers have addressed this particular challenge variously. For instance, Bolaji Akinyemi, Nigeria's Minister of Foreign Affairs under the Babangida government called for an increase in budgetary allocation to his Ministry at the April 1986 Kuru Conference. According to him;

The running of a successful foreign policy requires a substantial financial outlay for the institutions charged with the implementation and execution of our foreign policy. It is a fact that active foreign policy and paltry budgetary allocation are mutually exclusive. Consequently, those who want Nigeria to play an active role in international affairs must advocate greater financial outlay for foreign policy programmes (Akinyemi, 1986).

But while Akinyemi proposed increased funding by government as an antidote to the financial embarrassment faced by Nigerian Missions abroad; Ambasador Olu Adeniji, Nigeria's Minister of Foreign Affairs between 2007 and 2008 under the Umar Musa Yar'adua administration, suggested a rationalization of the number of foreign embassies maintained by Nigeria. To him, this will help government to conserve funds for national development instead of wasting money in maintaining a larger network of foreign missions that have not really been effective in advancing the Nigeria's national interests and foreign policy objectives over the years (Adeniji, 1990: 152) It need be observed that the reports of the funding challenges faced by Nigerian missions abroad probably informed the call for rationalization of the number of embassies Nigerians maintains abroad. But apart from this policy action, it is also vital to emphasize the need for prudent management of whatever funds allocated to each foreign mission, particularly at this period of economic crisis. The principles of accountability and responsibility in fund management should be embraced by Nigerian diplomats. This will go a long way to enhance the efficiency and effectiveness of foreign missions in the performance of their duties at minimal cost.

Another major challenge that faced the foreign missions was the conflict of interest between the Head of Mission and the Head of Chancery. This particular problem was very prominent between 1960 and 1987 and was a direct off-shoot of the ambiguity in the organizational structure of Nigeria's foreign missions then. The basic organization of a mission was such that in addition to the Head of Mission, there was also a Head of Chancery. The Head of Chancery, as the Accounting Officer of the Mission, derived his authority from the Permanent Secretary who, until 1987, was the 
Accounting Officer of the Ministry of Foreign Affairs. This arrangement was intended to ensure that a civil servant versed in the financial rules and regulations of government assisted the Head of Mission with proper disbursement of the Mission's funds. Unfortunately, however, rather than enhancing the efficiency and effectiveness of mission activities, the arrangement was perhaps a very potent source of conflict between the Heads of Mission and the Heads of Chancery. It was particularly difficult for noncareer Heads of Mission to accept any diminution of their authority by their own subordinate officers. Credit must however be given to the Foreign Ministry officials for making firm attempts at reducing the conflict of interest whenever they surfaced then. The conflict, however appeared to have been permanently resolved by the civil service reforms of 1988 through which the Permanent Secretary ceased to be the Accounting officer of the Ministry (The Vanguard, 18 August 1999).

\section{Conclusion}

This paper traced the emergence of the Nigerian foreign policy and her foreign embassies to 1957 under Tafawa Balewa. It examined the structure, role and the challenges of Nigeria's missions abroad. In as much as these missions have been trying to project Nigeria's foreign policy objectives and principles over the years, it need be observed that the role of her embassies should be redefined and to make them live up to national expectations. In this respect, the Nigerian government must take pro-active actions at empowering the overseas missions. Apart from ensuring that the missions are staffed with competent hands, the training programme for diplomats should be reviewed to give them the necessary knowledge to practice the art and science of diplomacy because they are at the front line of her foreign policy implementation. Similarly, the missions should also be well funded by the government to meet their ever expanding tasks and responsibilities, just as Heads of Missions should be prudent in managing available resources at their disposal. It is hoped that if these observations are fully implemented by government, Nigerian foreign policy will be on track towards achieving the country's enunciated objectives and national interests.

\section{References:}

Adeniji, Olu. "Implementation and Administration of Foreign Policy: A Note on the Relationship between the Ministry of External Affairs and the Nigerian Missions Abroad” in Olusanya, G.O. and Akindele, R.A.(eds.) The Structure and Processes of Foreign Policy Implementation in Nigeria, 1960 - 1990. Lagos/Ibadan: NIIA and Vantage Publications International Ltd., 1990. 
Akinyemi, A.B. Welcome Address by Minister of External Affairs at the All Nigeria Conference on Foreign Policy, held at Kuru near Jos between 5 and 7 April, 1986.

Aluko, Olajide. "The Foreign Service”. The Quarterly Review of the Institute of Administration, University of Ife, Vol. V, No.1, October, 1970.

Azuh, Maureen “Ajibola carpets leaders over governance”, in The Punch, 30 December, 2011.

Brownlie, Ian. Principles of Public International Law. Oxford: Clarendon Press, 1980.

Chibundu, V.N., Foreign Policy with Particular Reference to Nigeria, 1961 - 2001. Ibadan: Spectrum Books Ltd., 2004.

Fafowora, Dapo. 50 years of the Nigerian Diplomatic Service. The Nation Website Search Archive, 24 April, 2008.

Federal Republic of Nigeria. Mr. Prime Minister: A Selection of Speeches made by Alhaji, The Right Honourable Sir Abubakar Tafawa Balewa, K.B.E., M.P., Prime Minister of the Federal Republic of Nigeria. Lagos: Nigerian National Press, 1964.

Financial Nigeria. July 11, 2012. Available online @: www.searchfinancialnigeria.com

Goldstar Publication Inc. The National Yearbook of Nigeria, 2002 - 2003. Lagos: Goldstar Publication, 2003.

House of Representatives Sessional Paper No. 11 "Federation of Nigeria: The Training of Nigerians for the Representation of their country overseas: A Statement of policy by the Government”. Lagos: Federal Government Press, 1956.

Idang, G. J. Nigeria: Internal Politics and Foreign Policy, 1960-1966. Ibadan: Ibadan University Press, 1973.

Johns, D.H. "Diplomatic Exchange and Interstate Inequality in Africa: An Empirical Analysis" in Shaw, T.M. and Heard, K.A. eds. The Politics of Africa: Dependence and Development. England: Longman Group Ltd, 1979. Jolaoso, Olujimi. In the Shadows: Recollections of a Pioneer Diplomat. Lagos: Malthouse Press Ltd., 1991.

Kawonishe, Dayo. "Salvaging Nigerian Missions from Financial Crisis". African Journal of International Affairs and Development, .8 (1), 2003.

Madueke, Ojo (nd) "Reps to tackle decay in Nigerian Missions", Report of Madueke's statement before the House of Representatives Committee on Foreign Affairs at: www.nigeriabestforum.com/index.php...

Nigerian Compass. “Tasks before New Ambassadors”, 26 June, 2012.

Nwosu, N.I. "The Structure of Foreign Policy-making in Nigeria". Unpublished Ph.D Thesis, University of Ibadan, 1991.

Ogunbambi, R.O. "Foreign Service: The Nigerian Ambassador and His Tasks”, Nigerian Journal of International Affairs, 12 (1\&2), 1986. 
Olusanya, G.O. "The Challenges of the Nigerian Foreign Service”, in G.O. Olusanya and R.A. Akindele (eds), The Structure and Processes of Foreign Policy Implementation in Nigeria, 1960 - 1990. Lagos/Ibadan: NIIA and Vantage Publications International Ltd., 1990.

Opara, G. "Reduction in Diplomatic Missions Affecting Nigeria- Minister", National Mirror, 2 February, 2016.

Orjiako, Umunna H. "The Ministry of Foreign Affairs and Nigeria's International Relations in an Evolving Global Environment: Prospects and Challenges " in Eze, Osita C (Ed.) Beyond Fifty Years of Nigeria's Foreign Policy: Issues, Challenges and Prospects. Lagos: Nigerian Institute of International Affairs, 2010.

Padelford, N.J. and Lincoln, G.A. The Dynamics of International Politics. New York: The Macmillan Company, 1967.

Palmer, N. D. and Perkins, H.C. International Relations: The World Community in Transition. New Delhi: CBS Publishers and Distributors, 1985.

The Vanguard,(Nigeria) 18 August 1999.

United Nations Organisation, Vienna Convention on Diplomatic Relations (1961) entered into force on 24 April, 1964. 